\title{
ФУНДАМЕНТАЛІЗАЦІЙНА СПРЯМОВАНІСТЬ НАВЧАННЯ ФІЗИКИ ТА ТЕХНІЧНИХ ДИСЦИПЛІН НА ОСНОВІ SТЕМ-ТЕХНОЛОГІЙ
}

\author{
Кузьменко О. С. \\ докторка педагогічних наук, дочентка, \\ професорка кафедри фізико-математичних дисциплін \\ Льотна академія \\ Наиіонального авіаиійного університету \\ вул. Добровольського, 1, Кропивницький, Украӥна \\ orcid.org/0000-0003-4514-3032 \\ Kuzimenko12@gmail.com
}

Савченко I. М.

кандидатка педагогічних наук, старша наукова співробітниия, учена секретарка

Національний центр «Мала академія наук Украӥни»

вул. Дегтярівська, 38-44, Київ, Україна

orcid.org/0000-0002-0273-9496

savchenko_irina@ukr.net

Ключові слова: фізика,

STEM-освіта, інтеграція, міждисииплінарність, STЕМ-складники, прикладний аспект, професійно зорієнтований підхід.
У статті розглядається аналіз поняття фундаменталізації та формування особливостей вивчення фундаментальних понять з урахуванням розвитку сучасних тенденцій вищої освіти. Фундаменталізація забезпечує універсальне, системоутворювальне, інваріантне знання та сприяє його відбору з величезного обсягу нової наукової інформації. У межах знаннєвої парадигми інноваційного розвитку на засадах STEM-освіти $\epsilon$ пошук шляхів розв'язання цієї проблеми на рівні універсальних надпредметних знань, до яких належать методологічні.

Окреслено принципи фундаменталізації, що грунтовно розкривають сутністьSTEM-освітніх показниківтаїх значеннядляподальшого вивчення професійно зорієнтованих дисциплін технічного закладу вищої освіти. Визначені нами принципи фундаменталізації свідчать про те, що зміст навчального матеріалу, форми, методи навчання, що використовуються в освітньому процесі 3 фізики на основі STEM-технологій, мають відповідати системній логіці побудови тих професійно зорієнтованих дисциплін, теоретичною основою яких є фізика. На основі цих знань студенти зможуть моделювати пізнавальні та практичні завдання прикладного характеру з урахуванням концепції STEM-освіти. Відповідно до зазначеного потрібно формувати фундаментальне ядро знань і уявлень 3 фізики та методологічних STEM-компетентностей, що є важливими для студентів у подальшому вивчення дисциплін прикладного характеру за освітніми програмами. Розв'язання цієї проблеми нами вбачається у визначенні міждисциплінарної інтеграції фізики та дисциплін технічного циклу через взаємозумовленість та взаємодоповненість науковості, емпірії та математизації. Відповідно, прослідковуючи фундаменталізацію змісту навчання фізики, потрібно враховувати узагальнені знання студентів на засадах STEM-освіти.

У статті розглянуто як приклад визначення центра мас крила літака, де визначено технічний складник STEM-освіти (будова літака та його 
частин), інженерний складник - використання програми 3D-max для 3D моделювання літака та його конструкцій, а для розрахункових обчислень студентами використовувалась програма Ехсеl. Визначено, що курс фізики для студентів технічного закладу вищої освіти потребує значної математизації та залучення елементів програмування, що сприятиме їхній адаптації до професійної діяльності, що зумовлено специфікою цих навчальних дисциплін.

\title{
FUNDAMENTALIZATION ORIENTATION OF PHYSICS AND TECHNICAL DISCIPLINES BASED ON STEM-EDUCATIONAL SPACE
}

\author{
Kuzmenko O. S. \\ Doctor of Pedagogical Sciences, Associate Professor, \\ Professor at the Department of Physics and Mathematics Disciplines \\ Flight Academy \\ of the National Aviation University \\ Dobrovolsky str., 1, Kropyvnytskyi, Ukraine \\ orcid.org/0000-0003-4514-3032 \\ Kuzimenko12@gmail.com
}

\author{
Savchenko I. M. \\ Ph. D. in Pedagogy, Senior Researcher, \\ Science Secretary \\ National Center "Junior Academy of Sciences of Ukraine" \\ Dehtiarivska str., 38-44, Kyiv, Ukraine \\ orcid.org/0000-0002-0273-9496 \\ savchenko_irina@ukr.net
}

Key words: physics,

STEM-education, integration, interdisciplinarity,

STEM-components, applied aspect, professionally-oriented approach.
The article considers the analysis of the concept of fundamentalization and the formation of features of the study of fundamental concepts taking into account the development of modern trends in higher education. Fundamentalization provides universal, system-forming, invariant knowledge and facilitates its selection from a huge amount of new scientific information. Within the knowledge paradigm of innovative development on the basis of STEM-education is the search for ways to solve this problem at the level of universal supra-subject knowledge, which includes methodological.

The principles of fundamentalization are outlined, which thoroughly reveal the essence of STEM-educational indicators and their significance for further study of professionally oriented disciplines of a technical institution of higher education. The principles of fundamentalization defined by us indicate that the content of educational material, forms, teaching methods used in the educational process of physics on the basis of STEM-technologies should correspond to the system logic of construction of those professionally oriented disciplines, the theoretical basis of which is physics. Based on this knowledge, students will be able to model the cognitive and practical tasks of an applied nature, taking into account the concept of STEM-education. According to the above, it is necessary to form a fundamental core of knowledge and ideas in physics and methodological STEM-competencies, which are important for students in the further study of applied disciplines in educational programs. We see the solution to this problem in determining the interdisciplinary integration of physics and disciplines of the technical cycle through the interdependence and complementarity of science, empiricism and mathematization. Accordingly, following the fundamentalization of the content of teaching physics, it is necessary to take into account the generalized knowledge of students on the basis of STEM-education. 
The article is considered as an example of determining the centre of mass of the wing of the aircraft, which defines the technical component of STEM-education (structure of the aircraft and its parts), engineering component - the use of 3D-max for 3D modelling of aircraft and its structures, and Excel used calculations for calculations. It is determined that the course of physics for students of technical institutions of higher education requires significant mathematization and involvement of programming elements, which will facilitate their adaptation to professional activities, due to the specifics of these disciplines.

Постановка проблеми. У сучасному освітньому просторі притаманні швидкі зміни щодо впровадження нововведень та інноваційних технологій (STEM, SMART, BYOND та ін.). Це відповідає наявності в освітньо-науковому середовищі закладу вищої освіти (ЗВО) сучасних тенденцій до прагматизації професійно зорієнтованої вищої освіти за європейськими стандартами освітніх систем. Щодо навчання фізики на основі STEM-технологій потрібно акцентувати увагу на формуванні фундаментальності наскрізних генеруючих понять, створенні фізичної аксіоматичної бази для вивчення професійно зорієнтованих дисциплін та окресленні прикладного аспекту фізики як важливої науки для підготовки фахівців інженерного та технічного профілей навчання.

Зазначимо, що фізична освіта потребує подальшої фундаменталізації щодо світоглядних моделей та практично значущих аспектів дидактики фізики на засадах STEM-освіти. 3 іншого боку, потрібно враховувати запити та інтелектуальний потенціал здобувачів вищої освіти фізико-технічної освіти, створення умов формування в них наукового способу мислення та відповідного рівня їх STEM-компетентності.

Звернемо увагу на те, що потрібно враховувати профіль навчання майбутньої діяльності фахівців в умовах цифровізації України та розроблення нової методики навчання фізики з урахуванням концепції STEM-освіти, що впроваджуватимуться в освітньому процесі через призму нормативного забезпечення (освітніх, навчальних програм, силабуси, методичного забезпечення тощо).

Питанням фундаменталізації у навчанні фізики щодо засвоєння знань окреслено в працях: А.І. Субетто, Н.Ф. Тализіної, О.В. Хуторського; принципів фундаменталізації освіти С.У. Гончаренка, 3.I. Слєпкань; фундаменталізації в закладах вищої освіти - Н.В. Подопригори, С.О. Семерікова, О.В. Сергєєва, М.І. Садового та ін.

Важливим аспектом фундаменталізації фізичної освіти може бути створення умов для забезпечення цілісного сприйняття матеріалу загального курсу фізики студентами, що сприяло б формуванню певного цілісного погляду на фізичну науку i, відповідно, на фізичний навколишній світ, який вона описує.

Учений О.А. Коновал [1] розглядає фундаменталізацію фізичної освіти через цілеспрямовану педагогічну діяльність здобувачів вищої освіти та викладачів, яка розглядає виконання методологічної, професійно зорієнтованої, розвивальної, прогностичної та інтегративної функцій. Саме це сприяє розвитку інваріантних знань, що потрібні для професійної діяльності фахівців технічного профілю; проникнення фізичної освіти в практично зорієнтовану діяльність; розвиток пізнавальної активності та мотивація до вивчення фізики як грунтовної дисципліни щодо потреб суспільства та прикладного аспекту навчання.

До фундаменталізації навчання, за словами С.Я. Казанцева, потрібно віднести такі напрями:

- створення системи освіти, націленої на розвиток інваріантних знань;

- перехід від «освіти на все життя» до «освіти протягом усього життя»;

- орієнтація на засвоєння глибинних, сутнісних зв'язків і підстав, складових частин цілісної наукової картини світу, онтологічну і гносеологічну єдність методології і пізнавальної діяльності [2].

У процесі вивчення курсу фізики в Льотній академії Національного авіаційного університету (Льотна академія НАУ) студенти знайомляться 3 експериментальним методом дослідження фізичних явищ і процесів природи, аналізом, синтезом, систематизацією спостережуваних явищ фізичного експерименту з використанням STEM-освітніх технологій.

Слід відзначити, що одним із напрямів реформування фізичної освіти у закладах вищої освіти $\epsilon$ посилення іiі методологічної спрямованості на засадах STEM-освіти. Тому виникає потреба, щоб фізика як наука сприймалась суб'єктом навчання не як перелік відкриттів чи наявність формул, а відповідно, формувала наукове мислення у процесі пізнання навколишнього світу та фундаментальну науку у процесі опанування професійно зорієнтованими дисциплінами.

Рівень сформованості знань у студентів із фізики визначається засвоєнням фундаментальних фізичних понять, законів, теорії та принципів.

У сучасній фізиці виявлено певний взаємозв'язок фізичних законів і принципів симетрії. Особливо актуальні питання, пов'язані з теорією симетрії в сучасних фізичних теоріях, заснованих на об'єднанні фундаментальних взаємодій.

На нашу думку, варто сформувати у студентів під час навчання фізики цілісне уявлення 
про дану науку, відповідно, на основі вивчення фундаментальних понять одним із них $є$ матеріальна точка, та окреслити важливість наскрізних понять фізики у прикладному аспекті дисциплін технічного профілю.

Мета статті полягає в розкритті поняття та принципу фундаменталізації; визначенні особливостей методики навчання фізики на основі технологій STEM-освіти на основі міждисциплінарного, особистісно зорієнтованого та інтегрованого підходів в освітньому процесі технічного ЗВО; розгляді практично прикладного аспекту фізики з окресленням складників STЕМ-освіти.

Виклад матеріалу. У процесі нашого дослідження ми проаналізували дефініції «фундаменталізація», «фундаментальні знання» та «принцип фундаменталізації» у навчанні фізики, що є основою для вивчення студентами професійно зорієнтованих дисциплін технічного профілю.

Згідно 3 Академічним тлумачним словником [3] «фундаментальний» - міцний, великий, зроблений на тривалий час.

Науковець О.В. Сергєєв окреслює фундаменталізацію через взаємозв'язки теоретичної та практичної підготовки суб'єкта навчання, що сприятиме формуванню наукової картини світу та індивідуально-професійному розвитку студента, забезпечуватиме високу якість освіти [4].

Із переходом освітнього процесу на професійно зорієнтований напрям М.О. Читалін виділив функції фундаменталізації освіти:

- визначення змісту навчального предмету 3 урахуванням його особливостей;

- наступності та теоретичного узагальнення знань $з$ фізики;

- психологічних і педагогічних особливостей сприйняття, засвоєння, застосування, аналізу й синтезу навчального матеріалу здобувачами вищої освіти [5].

Згідно із тлумаченням науковиці Н.Ф. Тализіної «фундаментальні знання - це системоутворювальні, методологічно значущі уявлення»... вони необхідні суб'єкту навчання для самостійного здобуття знань, що допомагатимуть йому у процесі зміни професійного фаху» [6].

За дослідженнями С.I. Архангельського, фундаментальні знання розглянуто як «основоположні у змісті конкретної дисципліни» [7].

До гносеологічних аспектів фізичного знання структуру його типології, яку наводить О.Н. Голубева [8, С. 149-150], належать: 1) фундаментальні парадигми; 2) фундаментальні концептуальні підходи; 3) принципи та конвенцій; 4) фундаментальні фізичні теорії; 5) прикладні та фізичні теорії.

Отже, аналіз знань, набутих у різних предметних галузях, дає підстави стверджувати, що їх накопичення відбувається переважно шляхом збільшення обсягу нових і нових часткових явищ, нових часткових залежностей, основа ж є інтегрованою - спільною, проте, 3 погляду дидактики, добір нових знань до змісту навчальної дисципліни має бути обгрунтованим.

Науковиця Г.Я. Дутка [9, с. 45-50] виділяе фундаменталізацію освіти через принципи дидактики, що прийняті нами для визначення важливості фундаментальності у навчанні фізики з окресленням

STEM-складників в освітньому процесі технічного ЗВО:

1) принцип науковості - розглядається фундаментальний компонент змісту освіти 3 технічного напряму (STEM-складники: науковості, інженерії, математики, технічності);

2) принцип оптимізації навчального процесу 3 фізики на засадах STEM-освіти в технічному 3BO;

3) принцип зорієнтованості на формування єдності знань і вмінь, свідомості та поведінки розглядається фундаменталізація навчання фізики та професійно зорієнтованих дисциплін на основі STEM-технологій в умовах інтегрованого, міждисциплінарного та професійно зорієнтованого підходів;

4) принцип розвитку ініціативи i самостійності, свідомості й активності в опануванні нових знань стосовно тенденцій розвитку сучасної освіти в ЗВО - застосування фундаментальних знань 3 фізики на засадах STEM-освіти [10];

5) принцип систематичності й послідовності знань і вмінь суб'єктів навчання з фізики на основі STEM-технологій, де фундаменталізація виступає вагомим фактором забезпечення систематичності та послідовності отриманих знань;

6) принцип творчої активності та самостійності - фундаменталізація визначає рівень формування пізнавально-пошукової діяльності та творчої активності у навчанні фізики на основі STEM-технологій;

7) принцип усвідомленості та грунтовності знань, де фундаментальні знання $є$ стрижнем для забезпечення усвідомленості та грунтовності професійних знань (розгляд фундаментальних наскрізних генеруючих понять 3 фізики);

8) принцип цілеспрямованості та мотивації визначається фундаментальний компонент змісту освіти як чинник мотивації студентів до вивчення фізики.

Нами виділено основні положення щодо принципу фундаменталізації з фізики 3 урахуванням технологій STEM-освіти (таблиця 1), визначено важливість цієї дефініції як дидактичного принципу 3 урахуванням інтегрованого, міждисциплінарного та особистісно зорієнтованого підходів. 
Таблиця 1 на основі STEM-технологій в умовах професійно

Сутність принципу фундаменталізації знань 3 фізики на засадах STEM-освіти для технічного $3 B 0$

\begin{tabular}{|c|l|}
\hline $\begin{array}{c}\text { № } \\
\text { 3/II }\end{array}$ & \multicolumn{1}{|c|}{ Положення принципу фундаментальності } \\
\hline 1 & $\begin{array}{l}\text { фнань із фізики } \\
\text { знань не зводитьстя до фундаменталальності нау- } \\
\text { кових знань }\end{array}$ \\
\hline 2 & $\begin{array}{l}\text { фундаментальність наукового знання не зво- } \\
\text { диться до науково-раціонального знання, вона } \\
\text { припускає і наукову інтуїцію }\end{array}$ \\
\hline 3 & $\begin{array}{l}\text { фундаментальність знань із фізики базується } \\
\text { на науковій і філософській рефлексії викла- } \\
\text { дача, хоча вони пристосовані до «концептуаль- } \\
\text { ної системи» студента }\end{array}$ \\
\hline 4 & $\begin{array}{l}\text { фундаментальність знань є універсальними, } \\
\text { спрямованими на сприйняття суб'єктом нав- } \\
\text { чання світу як цілого }\end{array}$ \\
\hline 5 & $\begin{array}{l}\text { фундаментальне знання - це знання, звернене } \\
\text { до законів, за якими функціонує і розвивається } \\
\text { суб'єкт навчання }\end{array}$ \\
\hline 6 & $\begin{array}{l}\text { фундаментальні знання, як найважливіше } \\
\text { «ядро», містять знання рефлексій і мета знання }\end{array}$ \\
\hline
\end{tabular}

Отже, відзначимо, що принцип фундаменталізації передбачає визначення змісту навчання, спрямованого на формування в студентів інваріантних, усталених знань, умінь й інших компетенцій у навчанні фізики на засадах STEM-освіти. Тому йдеться про формування індивідуальних якостей особистості, здатності студентів реалізовувати здобуті знання, вміння й інші компетенції у навчанні фізики зорієнтованого, міждисциплінарного та інтегрованого підходів, що формується в процесі навчальнопізнавальної діяльності. Отже, фундаменталізація забезпечує формування в студентів довготривалої системи фундаментальних знань і вмінь 3 фізики на основі STEM-технологій в технічному ЗВО.

Розглянемо завдання, що виконується студентами Льотної академії НАУ на розрахунок центр мас спорядженого крила, після того як вони побудували $3 \mathrm{D}$ модель літака за допомогою програми 3D Max (рис. 1).

Під масою спорядженого крила ми розуміємо суму мас його конструкції, що розташована в крилі обладнання, двигунів, пілонів, палива, що розраховане на політ. Завдання студентів - розрахувати центр мас характерних об'єктів крила: конструкції крила, рідини та масла, основної та носової опори шасі, що знаходиться у випущеному стані, а також теоретичні відомості щодо виконання завдань знаходяться в збірниках [11-14].

Результати виконаних розрахунків за допомогою програми Excel щодо визначення координат центра мас крила літака, вантажів наведено в таблиці 2.

Після розрахунку студентами центра мас крила літака доцільно розв'язати фізичну задачу на знаходження координати центру мас і статистичних моментів і виокремити STEM-показники та розглянути міждисциплінарну інтеграцію, що наведена нами в таблиці 3 (фрагмент дослідженого матеріалу) для спеціальності 272 Авіаційний транспорт.

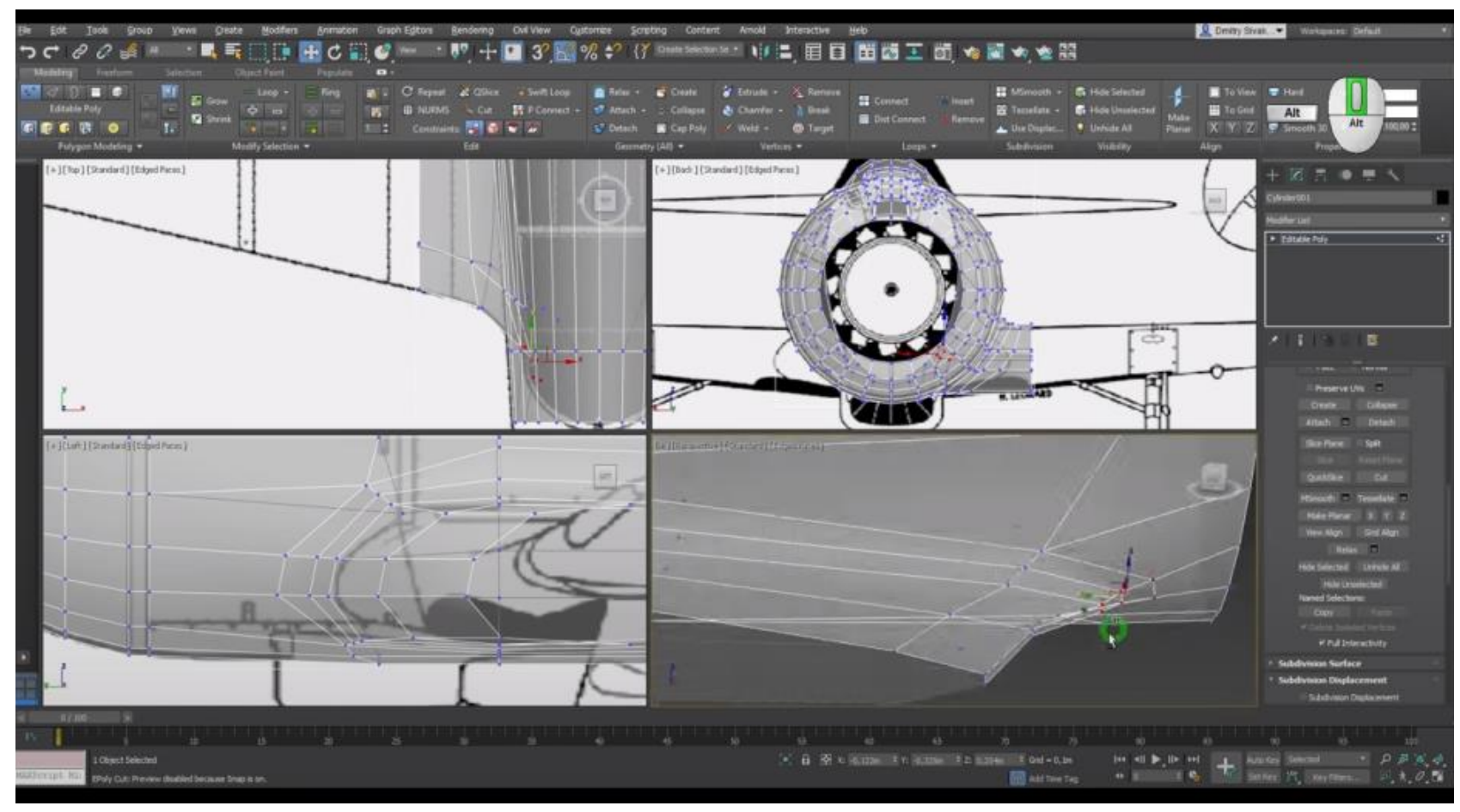

Рис. 1. Моделювання літака за допомогою програми 3D Max 
Таблиця 2

Розрахункові дані центра мас крила літака

\begin{tabular}{|c|c|c|c|c|}
\hline № 3/II & Назва об’скта & Maca m $\mathbf{m}_{i}, \mathbf{к}$ & $\begin{array}{c}\text { Координата } \\
\text { центра мас, } X_{i}, \text { м }\end{array}$ & $\begin{array}{c}\text { Момент маси, } \\
\mathbf{m}_{i} X_{i}, \mathbf{k} \Gamma \mathbf{m} \\
\end{array}$ \\
\hline 1 & Крило (конструкція) & 14876,648 & 4,517 & 67197,81902 \\
\hline 2 & Паливна система & 788,327 & 4,517 & 3560,873059 \\
\hline 3 & Силова установка & 21695,781 & $-0,03$ & $-650,87343$ \\
\hline 4 & Мастила та робочі рідини & 252 & 0,706 & 177,912 \\
\hline 5 & Управління літаком (30\%) & 218,742 & 4,689 & 1025,681238 \\
\hline 6 & Електрообладнання 30\% & 1329,685 & 0,868 & 1154,16658 \\
\hline 7 & Протиобліднювальна система (70\%) & 1275,189 & 0,868 & 1106,864052 \\
\hline 8 & Гідросистема (70\%) & 1577,837 & 4,689 & 7398,477693 \\
\hline 9 & Споряджене крило без палива та шасі & 40826,769 & 1,577 & 64383,81471 \\
\hline 10 & Передня опора - «Випущено» & 705,32 & $-10,499$ & $-7405,15468$ \\
\hline 11 & Основна опора - «Випущено» & 5678,833 & 4,087 & 23209,39047 \\
\hline 12 & Паливо (з аеронавігаційним запасом) & 27981,734 & 3,815 & 106750,3152 \\
\hline 13 & Паливо в баках № 1, 2 & 10000 & 2,756 & 27560 \\
\hline 14 & Паливо в баках № 3, 4 & 10000 & 3,723 & 37230 \\
\hline 15 & Паливо в баках № 5, 6 & 7681,744 & 5,123 & 39353,57451 \\
\hline & Разом & 144888,609 & 31,406 & 4550371,654 \\
\hline
\end{tabular}

Таблиця 3

Міждисциплінарні зв'язки фізики та дисциплін професійно зорієнтованого профілю технічного ЗВО щодо вивчення поняття центра мас (фрагмент таблиці)

\begin{tabular}{|c|c|c|}
\hline \multicolumn{3}{|r|}{$\begin{array}{c}\text { Професійне спрямування: Обслуговування повітряного руху } \\
\text { Варіативна компонента: «Управління повітряним рухом» }\end{array}$} \\
\hline $\begin{array}{l}\text { № } \\
3 / \text { II }\end{array}$ & $\begin{array}{c}\text { Тема } \\
\text { дисципліни } \\
\text { «Фізика» }\end{array}$ & Розділ предмета професійного спрямування, який зорієнтований на цю тему \\
\hline 1 & $\begin{array}{c}\text { Динаміка } \\
\text { механічних } \\
\text { систем }\end{array}$ & $\begin{array}{l}\text { Теоретична механіка. } \\
\text { Тема 5. Центр мас. Центрування літака. } \\
\text { Тема 15. Динаміка системи. Моменти інерції твердого тіла. Теорема про рух центру мас системи. } \\
\text { Механічна система. Класифікація сил, що діють на механічну систему. Маса системи. Центр мас } \\
\text { системи. Диференціальні рівняння руху механічної системи. Теорема про рух центра мас системи. } \\
\text { Диференціальні рівняння руху центра мас системи. Закон збереження руху центра мас системи. } \\
\text { Повітряні перевезення. } \\
\text { Тема } 3 \text { Термінологія. Маса порожнього літака. Маса порожнього спорядженого літака. Маса екі- } \\
\text { пажа. Маса бортпровідників. Маса продуктів харчування. Максимальна маса комерційного заванта- } \\
\text { ження. Гранична маса комерційного завантаження та ін. Центрувальні характеристики ПС. } \\
\text { Тема } 5 \text { Процедура визначення маси літака та балансувальна документація. Додавання маси пасажи- } \\
\text { рів та вантажів. Додавання маси палива. } \\
\text { Тема } 8 \text { Розрахунок центру тяжіння. Центр тяжіння при пустих масах. Рух центра мас тяжіння при } \\
\text { заливці палива, навантаженні та завантаженні баласту. } \\
\text { Тема } 10 \text { Навантаження на одиницю площі, вантаж: який переміщується, підтримка вантажу. Пере-- } \\
\text { міщення центру тяжіння за встановленні межі. Пошкодження через інерцію навантаження. } \\
\text { Вища математика. } \\
\text { Тема 6. Поняття вектора, дії над векторами. }\end{array}$ \\
\hline \multicolumn{3}{|r|}{ Професійне спрямування: Льотна експлуатація повітряних суден } \\
\hline 2 & $\begin{array}{c}\text { Динаміка } \\
\text { механічних } \\
\text { систем }\end{array}$ & $\begin{array}{l}\text { Аеродинаміка польоту повітряних суден. } \\
\text { Тема 5. Балансування, стійкість та керованість літака. Схема сил, що діють на літак: реальна та приве- } \\
\text { дена до центра мас збалансованого літака. Центр аеродинамічного тиску та фокус. Центрування літака. } \\
\text { Тема 12. Стійкість, керованість та балансування літака в повздовжньому русі. } \\
\text { Балансування літака в повздовжньому русі. Центрування за допомогою баласту та вантажу. } \\
\text { Теоретична механіка. } \\
\text { Тема 15. Динаміка механічної системи матеріальних точок. } \\
\text { Повітряні перевезення. } \\
\text { Тема } 3 \text { Термінологія. Маса порожнього літака. Маса порожнього спорядженого літака. Маса екі- } \\
\text { пажа. Маса бортпровідників. Маса продуктів харчування. Максимальна маса комерційного заванта- } \\
\text { ження. Гранична маса комерційного завантаження. } \\
\text { Тема } 5 \text { Процедура визначення маси літака та балансувальна документація. Додавання маси пасажи- } \\
\text { рів та вантажів. Додавання маси палива. } \\
\text { Тема } 8 \text { Розрахунок центру тяжіння. Центр тяжіння при пустих масах. Рух центра мас тяжіння при } \\
\text { заливці палива, навантаженні та завантаженні баласту. } \\
\text { Тема } 10 \text { Навантаження на одиницю площі, вантаж: який переміщується, підтримка вантажу. } \\
\text { Переміщення центру тяжіння за встановленні межі. }\end{array}$ \\
\hline
\end{tabular}


Отже, важливим аспектом розвитку STEM-компетентності у студентів технічного ЗВО є фундаменталізація фізики як грунтовного чинника щодо впровадження інноваційних STEM-технологій. Однак, слід зазначити, що професіналізація навчально-пізнавальної діяльності студентів 3 фізики суперечить принципу фундаменталізації, тому слід уникати уривчастих, фрагментарних відомостей, опосередкованих до змісту навчання тих дисциплін, що вивчаються на старших курсах, оскільки студенти не мають досвіду і знаннєвої бази для сприйняття такої інформації. Подолання зазначеної суперечності ми вбачаємо в можливостях інтеграційного підходу до навчання фізики та професійно зорієнтованих дисциплін на основі технологій STEM-освіти.

Висновки. У навчальному курсі $з$ дисципліни «Фізика» потрібно формувати концептуальні світоглядні уявлення стосовно фундаментальних фізичних понять та акцентувати увагу на вивченні цих питань 3 урахуванням тенденцій розвитку STEM-освіти. Відзначимо, що фундаментальні фізичні поняття, властивості матеріального світу пізнаються емпіричним шляхом, а формування уявлень про фундаментальні основи фізики має відбуватися 3 урахуванням прикладного характеру технічного спрямування на основі фізичних моделей.

\section{ЛІТЕРАТУРА}

1. Коновал О.А. Теоретичні і методичні засади вивчення електродинаміки як релятивістської теорії у вищих педагогічних навчальних закладах : дис. ... д-ра пед. наук : 13.00.02. Київ, 2010. 468 с.

2. Казанцев С.Я. Дидактические основы фундаментализации обучения в системе высшего образования. Казань : Изд-во Казан. ун-та, 2000. 138 с.

3. Академічний тлумачний словник. URL : http://sum.in.ua/s/fundamentaljnyj.

4. Сергєєв О.В. Фундаменталізація освіти у вищій школі. Теорія та методика навчання фундаментальних дисииплін у вищій школі : збірн. наук. пращь. 2005. С. 4-7.

5. Читалин Н.А. Фундаментализация профессионального образования. Профессиональное образование. Казанский педагогический журнал. 2000. № 2(19). С. 11-15.

6. Талызина Н.Ф. Педагогическая психология : учеб. пособ. для студ. сред. пед. учеб. заведений. Москва : Издательский центр «Академия», 1998. 288 с.

7. Архангельский С.И. Лекции по научной организации учебного процесса высшей школе. Москва : Высшая школа, 1976. $200 \mathrm{c}$.

8. Голубева О.Н. Теоретические проблемы общего физического образования в новой образовательной парадигме : дисс... д-ра пед. наук. Санкт-Петербург, 1995. 314 с.

9. Дутка Г.Я. Принцип фундаменталізації у професійній освіті. Педагогіка і психологія професійної освіти. 2006. № 6. С. 45-50.

10. Кузьменко О.С. Теоретичні і методичні засади навчання фізики студентів технічних закладів вищої освіти на основі технологій STEM-освіти : дис. ... д-ра пед. наук. Кропивницький, 2020. 622 с.

11. Гаража В.В. Конструкция самолетов : учебник. Киев : КМУГА, 1998. 524 с.

12. Челюканов И.П., Гаража В.В., Лукин В.И. Компоновка и центровка самолета : метод. указ. Киев : КИИГА, 1989. $48 \mathrm{c.}$

13. Конструкция и прочность летательных аппаратов : Альбом-приложение к методическим указаниям. Киев : КИИГА, 1990. $91 \mathrm{c.}$

14. Челюканов І.П., Гаража В.В., Кириленко О.Б. Конструкція літаків : метод. реком. до вик. курсов. роботи. Київ : НАУ, 2005. 80 с.

\section{REFERENCES}

1. Konoval, O. A. (2010) Teoretychni i metodychni zasady vyvchennja elektrodynamiky jak reljatyvistsjkoji teoriji u vyshhykh pedaghoghichnykh navchaljnykh zakladakh. (Dysertacija doktora pedaghoghichnykh nauk). Kyiv.

2. Kazantse, S. Ya. (2000). Didakticheskie osnovy fundamentalizacii obucheniya v sisteme vysshego obrazovaniya. Kazan.

3. Akademichnyj tlumachnyj slovnyk. URL: http://sum.in.ua/s/fundamentaljnyj

4. Sergeev, O. V. (2005). Fundamentalizacija osvity u vyshhij shkoli [Fundamentalization of education in higher education]. Theory and methods of teaching fundamental disciplines in higher education: collection. Science. wash, P. 4-7.

5. Chitalin, N. A. (2000). Fundamentalizaciya professional'nogo obrazovaniya. [Fundamentalization of vocational education]. Vocational education. Kazan pedagogical magazine. Vol. 2 (19). P. 11-15.

6. Talyzina, N. F. (1998). Pedagogicheskaya psixologiya : ucheb. posob. dlya zavedenij. Moscow : Publisher Center Academy. 
7. Arkhangelskyi, S. I. (1976). Lekcii po nauchnoj organizacii uchebnogo processa vysshej shkole. Moscow : Higher school.

8. Golubeva, O. N. (1995). Teoreticheskie problemy obshhego fizicheskogo obrazovaniya $v$ novoj obrazovatel'noj paradigme. (Dysertacija doktora pedaghoghichnykh nauk). Sankt-Peterburg.

9. Dutka, G. Ya. (2006). Pryncyp fundamentalizaciji u profesijnij osviti. [The principle of fundamentalization in vocational education]. Pedagogy and psychology of vocational education. Vol. 6. P. 45-50.

10. Kuzmenko, O. S. (2020). Teoretychni i metodychni zasady navchannja fizyky studentiv tekhnichnykh zakladiv vyshhoji osvity na osnovi tekhnologhij STEM-osvity (Dysertacija doktora pedaghoghichnykh nauk). Kropyvnytskyi.

11. Garazha, V. V. (1998). Konstrukciya samoletov: uchebnik. Kyiv : KMUGA.

12. Chelyukanov, I. P., Garazha, V. V., \& Lukin, V. I. (1989). Komponovka i centrovka samoleta : metod. ukaz. Kyiv : KIIGA.

13. Konstrukciya i prochnost' letatel'nyx apparatov : Albom-prilozhenie k metodicheskim ukazaniyam. (1990). Kyiv : KIIGA.

14. Chelyukanov, I. P, Garage, V. V, \& Kirilenko, O. B. (2005). Konstrukciya litakiv : metod. rekom. do vik. kursov. roboti. Kyiv : NAU. 